\title{
ВІЗУАЛІЗАЦІЯ ТЕМПЕРАТУРНИХ ПАРАМЕТРІВ КОНВЕКЦЙНО-ІНФРАЧЕРВОНИХ ПОТОКІВ ТЕРМОХІРУРГІЧНОГО ІНСТРУМЕНТУ
}

Худещький І. Ю., проф., д.м.н. igorkhudetskyy@gmail.com

Факультет біомедичної інженерії Національний технічний університет «Київський політехнічний інститут імені Ігоря Сікорського» м. Київ, Україна Інститут електрозварювання ім. Є. О. Патона НАН України, Київ, Україна Хрептун $\boldsymbol{C}$. I., студент, khreptun.e@gmail.com Aнтонова-Paфi Ю. В., доцент каф. біобезпеки і здоров’я людини, к.т.н. Antonova-rafi@ukr.net Національний технічний університет «Київський політехнічний інститут імені Ігоря Сікорського» м. Київ, Україна

\begin{abstract}
Реферат - Хірургія являється одним з основних розділів в медицині. На даний момент иироко використовуються термохірургічні апарати для проведення оперативних втручань. 3 розвитком науково-технічного процесу в операційних з'являються все нові і нові апарати та пристрої, які використовують практично всі відомі фізичні впливи на тканини для виконання певних хірургічних маніпулячій.Ефективне надання хірургічної допомоги передбачає точне знання біофізичної взаємодії між електротермохірургічним інструментом та тканинами в рані. Визначення температурних параметрів конвекційно-інфрачервоного потоку термохірургічного інструменту є актуальною проблемою. Об'єктивна оиінка параметрів теплового потоку є запорукою правильної роботи термохірургічного інструменту, що призводить до успішного виконання оперативного втручання. В статті запропоновано новий метод реєстрації конвекційноінфрачервоного потоку термохірургічного інструменту, а саме розроблено лабораторний стенд для реєстрачії даного потоку. Завданням дослідження було провести порівняльний аналіз існуючих та запропонованого методів реєстраціі конвекційно-інфрачервоного потоку. На першому етапі проведено дослідження традиційного методу з використанням термометра на термопарі. Цей метод є найбільи неточним та трудомістким. На другому етапі для візуалізації потоку провели дослідження за допомогою вимірювальної площини. Вона не має метричних параметрів та розмітки. Сітка спотворює потік і вносить свої перешкоди. На основі результатів першого та другого етапу досліджень були обрані технічні вимоги до випробувально-дослідницького стенду реєстрачії конвекційно-інфрачервоних потоків. Запропонований стенд може використовуватись із сучасним тепловізійним обладнанням. Власний вплив стенду при реєстрації температурних параметрів потоку є мінімальним. Таким чином доведено, щзо запропонований метод є найбільш точним, не дорогим та не потребує багато часу для роботи. А також не потребує декількох осіб персоналу, достатньо лише одну людину.
\end{abstract}

Ключові слова - візуалізація, експериментальний стенд, термопара, тепловий потік, конвекційно-інфрачервоний потік, термохірургічна апаратура.

\section{I. Ветуп}

Хірургічні втручання залишають одними 3 найпоширеніших та найефективніших способів надання допомоги при травмах, пораненнях та при лікуванні багатьох захворювань людини. Провідними причинами травм та поранень людей $є$ дорожньо-транспортні пригоди, бойові дії у зоні АТО, виробничі аварії. Так, щороку в аваріях травмується понад 30 тисяч та гине близько 3 тисяч громадян [1].
Кількість поранених у зоні АТО коливаються від 3 до 10 тисяч щорічно [3].

Особливістю таких травм та поранень $\epsilon$ кровотечі та інфекційні ускладнення. Особливі труднощі виникають при зупинці кровотечі із паренхіматозних органів, таких як печінка.

Іншою особливістю таких ран є їх первинне інфікування. Коли людина отримує будь яку травму то розвивається інфекційних процес. Пацієнт до хірурга попадає на різних стадіях 
інфекційного процесу. Інфекційні ускладнення суттєво ускладнюють лікування та можуть бути причиною інвалідизації пацієнтів [10]. Оперативні втручання 3 приводу інфекційноускладненої патології є окремим розділом хірургії і має свою специфіку у виконанні маніпуляцій, а відповідно і вимог до апаратури та інструментів, що застосовуються для здійснення оперативних втручань.

Для надання допомоги при таких травмах та пораненнях перспективним $\epsilon$ застосування апарату БТА-300М1 вітчизняного виробництва. Цей апарат дає можливість проводити безкровні операції на всіх органах. Дозволяє зупиняти кровотечу i одночасно проводити дезінфекцію рани. Працює на принципі інфрачервоно-конвекційному випромінюванні. Під час оперативних втручань спочатку ділянка обробляється інфрачервоним конвекційним потоком і після того в цьому місці можна розрізати звичайними ножицями без краплі крові. Це важливо для пацієнтів, які приймають спеціальні препарати, які розріджують кров і вона не згортається. На такі випадки розрахована ця апаратура. В Україні за допомогою цього апарату вже проведено кількасот операцій $[2,5]$.

3 розвитком науково-технічного процесу в операційних з'являються все нові і нові апарати та пристрої, які використовують практично всі відомі фізичні впливи на тканини для виконання певних хірургічних маніпуляцій. За своєю складністю вони охоплюють значний діапазон: від простих пристосувань до хірургічних роботів.

Безконтактні технології мають очевидні переваги з точки зору біобезпеки пацієнта у порівнянні 3 контактними технологіями, де на зміну громіздким процедурам стерилізації багаторазового хірургічного інструменту сформувалась тенденція розробки достатньо дорогого одноразового інструменту та технологій його утилізації $[4,8]$.

Сучасні хірургічні технології передбачають застосування різноманітної термохірургічної апаратури. Разом $з$ тим ефективне надання хірургічної допомоги передбачає точне знання біофізичної взаємодії між електротермохірургічним інструментом та тканинами в рані. А це можливо лише тоді, коли ми знаємо параметри конвекційно-інфрачервоного потоку. Практичне застосування відомих методик має суттєві труднощі, бо зареєструвати параметри можна лише $з$ використанням термометра, що $\epsilon$ неефективним.

Таким чином, визначення температурних параметрів конвекційно-інфрачервоного потоку термохірургічного інструменту $є$ актуальною проблемою.

Застосування тепловізорів та пірометрів неможливе, бо немає температурного поля, яке ними можна зафіксувати. Ці прилади не пристосовані для визначення температурних параметрів потоку [9].

Нами запропоновано провести візуалізацію конвекційно-інфрачервоного потоку та пристосування для реєстрації температури з подальшою обробкою сигналу.

\section{II. Матеріали і методи}

\section{А. Обсяг дослідження}

Для дослідження була розроблена схема експериментів, яка включає:

Дослідження теплового потоку за допомогою термопари встановленому на традиційному вимірювальному стенді. Всього було проведено 10 експериментів.

Дослідження теплового потоку за допомогою вимірювальної площини встановленій на традиційному вимірювальному стенді. Всього було проведено 10 експериментів.

Дослідження теплового потоку за допомогою розробленого лабораторного стенду. Всього було проведено 10 експериментів.

Для впровадження поставлених задач були проведені лабораторні дослідження.

Матеріалом слугували результати.

Обсяг дослідів і замірів показано у табл. 1.

Таблиця 1. Головні напрямки та об'см дослідження

\begin{tabular}{|c|c|c|}
\hline Nog & Напрямки & Об'єM \\
\hline 1 & $\begin{array}{c}\text { Дослідження } \\
\text { на традиційному стенді } 3 \\
\text { використанням термопари }\end{array}$ & $\begin{array}{c}\text { Всього проведено } \\
2430 \text { замірів } \\
\text { в } 10 \text { експериментах } \\
\end{array}$ \\
\hline 2 & $\begin{array}{c}\text { Дослідження } \\
\text { на традиційному стенді з } \\
\text { використанням } \\
\text { вимірювальної площини }\end{array}$ & $\begin{array}{l}\text { Всього було прове- } \\
\text { дено } 270 \text { замірів } \\
\text { в } 10 \text { експериментах }\end{array}$ \\
\hline 3 & $\begin{array}{c}\text { Досліджування } \\
\text { за допомогою } \\
\text { лабораторного макету }\end{array}$ & $\begin{array}{c}\text { Всього було прове- } \\
\text { дено } 90 \text { замірів } \\
\text { в } 10 \text { експериментах }\end{array}$ \\
\hline
\end{tabular}

Проаналізувавши таблицю, бачимо, що запропонований макет потребую найменшої кількості замірів. Отримуємо параметри теплового потоку набагато швидше.

\section{B. Anаратура та методики досліджень}

Обладнання для технічних випробувань та засоби вимірювальної техніки:

- цифровий термометр 3 діапазоном вимі- 
рювання 0..1000 ${ }^{\circ} \mathrm{C}$ фірми Velleman DVM1090, похибка $\pm 2 \%, \pm 3$ одиниці молодшого розряду;

- секундомір;

- тепловізор Fluke Ti10;

В якості генератора візьмемо блок живлення апарату БТА-300M1.

Технічні характеристики:

Номінальна напруга мережі однофазного змінного струму частотою 50 Гц, В $220+$ $10 \%$; номінальна вихідна потужність при тривалості циклу 5 с, ВА 350; межі регулювання вихідної напруги при навантаженні 100 Ом (для всіх частот), В 10-200; габаритні розміри, мм $300 \times 220 \times 120$; маса, не більше, кг 4 .

\section{С. Термохірургічні інструменти}

Розроблено зразки інструменту для загальної хірургії. Мінімальні габарити робочої частини інструменту 80 х 8 × 8 мм при масі 60 г. Максимальна довжина робочої частини інструменту, діаметр і конфігурація сопла не обмежені. Можлива розробка спеціалізованого інструментарію.

Для оцінки теплового стану тканини під впливом конвекційно-інфрачервоного потоку в дослідженні використовувались контактні термометри та тепловізор.

Для обробки термограм використовуємо програму FLUKE SmartView.

\section{III. Основна частина}

На першому етапі застосували традиційну методику, яка базується на використані стандартного термометра на термопарі. Який розміщується у певній точці потоку де проводимо вимірювання. Взаємне розміщення потоку та термометра викликає суттєві труднощі. Параметри потоку вимірюються в 3 точках по висоті та в 9 точках по горизонталі, що дає змогу отримати картину потоку. Але це, або 27 термометрів одночасно, або по черзі. I точно не можна визначити де центр потоку, а де границі. Таким чином, цей метод забирає багато часу, він $є$ тяжким. Відтворення експерименту буде мати велику похибку.

На другому етапі для візуалізації потоку ми пішли шляхом "step-by-step". Провели дослідження за допомогою вимірювальної площини. Тепловий потік проходить через вимірювальну площину, і таким чином ми отримуємо температуру всіх точок потоку, які знаходяться в вимірювальній площині.
Показовим для цього методу є можливість розрахувати зріз температурного розподілу. Розподіл на різних відстанях від центру до країв потоку. Але саме сітка спотворює потік і вносить свої перешкоді.

У вимірювальній площині такі недоліки, як неможливість вимірювати температуру теплового потоку на декількох рівнях. Важко виміряти температуру на однаковій відстані від сопла термохірургічного інструменту. Вимірювальна площина не має метричних параметрів та розмітки.

Проведені на першому та другому етапі дослідження дали змогу запропонували застосувати трьохвимірний лабораторний стенд візуалізації потоку, який може використовуватися 3 сучасним тепловізійним обладнанням. На рис. 1 представлений зовнішній вигляд стенду.

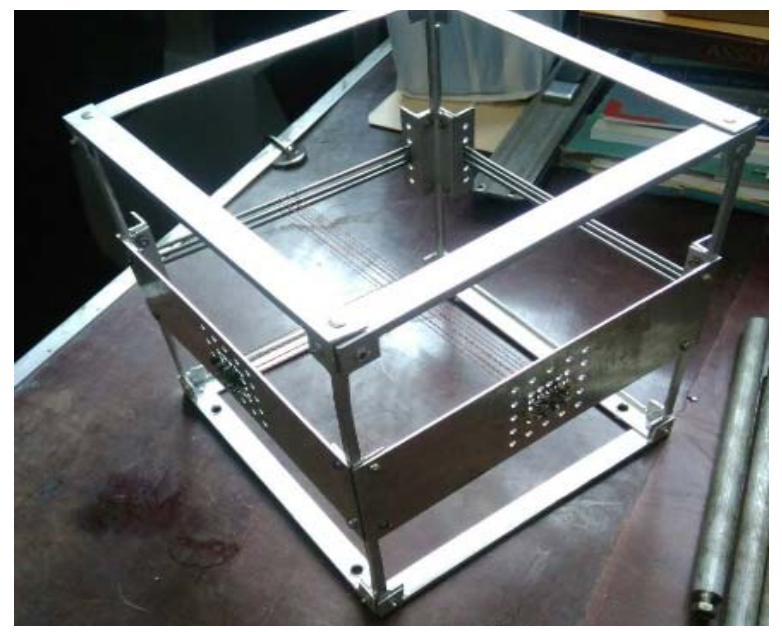

Puc. 1. Випробувально-дослідницький стенд реєстрації конвекційно-інфрачервоних потоків термохірургічного інструменту

Для того щоб отримати об'ємне зображення була вибрана фігура куба. Даний стенд має від трьох до семи плоскостей на різних рівня. Висоту рівнів можна регулювати 3 шагом 0.5 мм. Ці плоскості розташовані горизонтально одна під одній і складається с перехресної ніхромової проволоки. Щоб отримати не спотворену температуру в конкретних точках використовуємо струни. Це дає нам змогу одночасно реєструвати конвекційно-інфрачервоні потоки на різній висоті. Щоб мінімізувати прогинання струн використовуємо принцип само натяжної пружини. Проволока повинна бути тонка, щоб швидше охолоджувалась.

Власний вплив стенду на параметри потоку $\epsilon$ мінімальним. Ця модель дозволяє проводити автоматизований аналіз температурних потоків через використання зображення тепловізора, яке сканується з виділення точок 3 макси- 
мальною температурою та присвоєння номеру координати. I це в свою чергу дозволяє будувати математичну 3D модель конвекційноінфрачервоного потоку в динаміці. Патентний пошук по базі США не мав результатів, це означає що аналогів стенду немає. Запропонований стенд є оригінальним [6].

Для установки нашого стенду ми використали допоміжні прилади. Для подачі теплового потоку ми використовували термохірургічний інструмент термокоагулятор. Щоб термохірургічний інструмент закріпити нам потрібен фіксатор. Даний фіксатор має 2 подвійні вісі для регулювання висоти. Він дозволяє точно регулювати відстань від сопла до площини. Перша вісь для чорнового налаштування, друга вісь для більш точного, зі шкалою в мм.

Ми установили наш стенд, як показано на рис. 2.

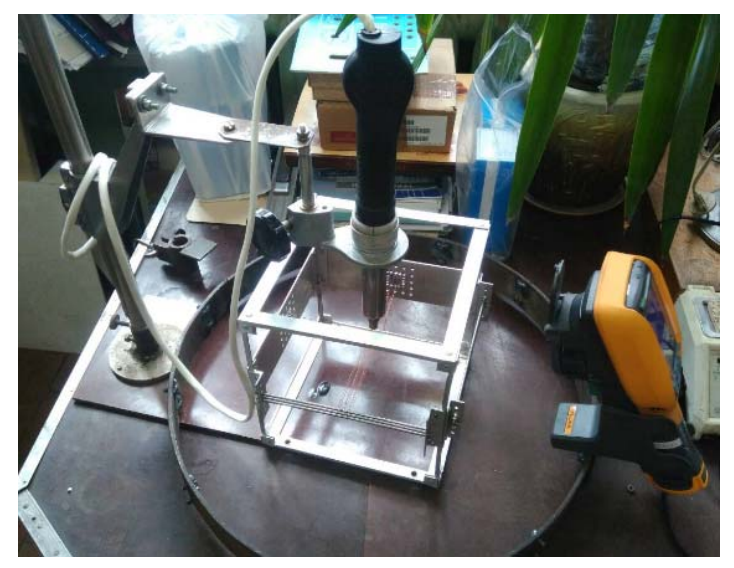

Рис. 2. Установка для реєстрації конвекційно-інфрачервоних потоків термохірургічного інструменту

Провели дослідження за допомогою стандартного термометра на термопарі (рис. 3) із спеціально підготовленою установкою.

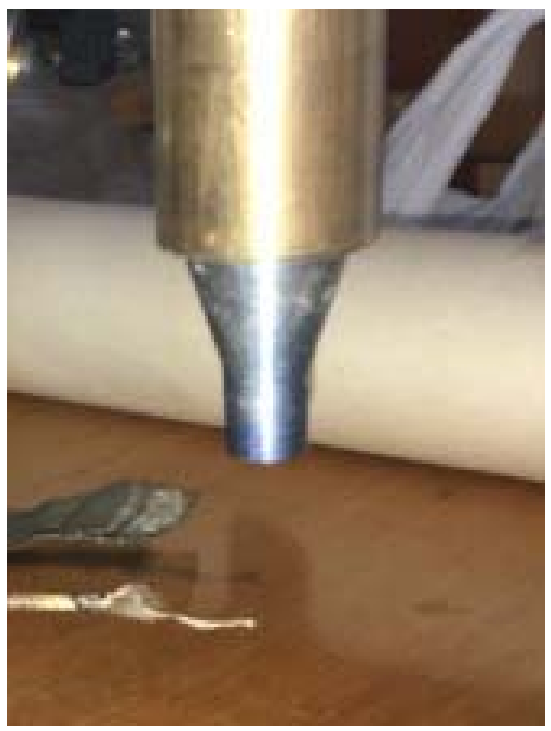

Puc. 3. Термопара
Було проведено 10 експериментів, при різних режимах температури та на різній висоті.

Проведені експерименти про $300{ }^{\circ} \mathrm{C}, 500{ }^{\circ} \mathrm{C}$ та $700{ }^{\circ} \mathrm{C}$. На відстані 1, 2, 3 см від сопла термохірургічного інструменту.Отримані результати представлені у таблиці 2.

Таблиця 2. Температурні параметри теплового потоку експерименту з термопарою

\begin{tabular}{|c|c|c|}
\hline $\begin{array}{c}\text { Tемпература } \\
\text { вимірювання, }{ }^{\circ} \mathrm{C}\end{array}$ & $\begin{array}{c}\text { Відстань від } \\
\text { сопла, см }\end{array}$ & $\begin{array}{c}\text { Tемпература } \\
\text { на зрізі сопла, }{ }^{\circ} \mathrm{C}\end{array}$ \\
\hline 300 & 1 & $129.8 \pm 24.0$ \\
\hline 300 & 2 & $121.6 \pm 19.7$ \\
\hline 300 & 3 & $107.2 \pm 18.7$ \\
\hline 500 & 1 & $122.4 \pm 18.7$ \\
\hline 500 & 2 & $113.3 \pm 18.5$ \\
\hline 500 & 3 & $92.8 \pm 17.4$ \\
\hline 700 & 1 & $178.8 \pm 21.8$ \\
\hline 700 & 2 & $153.5 \pm 18.1$ \\
\hline 700 & 3 & $133.8 \pm 20.7$ \\
\hline
\end{tabular}

Проаналізувавши дані, можна дійти висновку, що спосіб з термопарою $є$ дуже не точним, та трудомістким.

Похибка складає від $\pm 17.4^{\circ} \mathrm{C}$ до $\pm 24^{\circ} \mathrm{C}$.

Провели дослідження за допомогою вимірювальної площини (рис. 4) із спеціально підготовленим штативом. Також було проведено 10 експериментів, але з більшою кількістю точок.

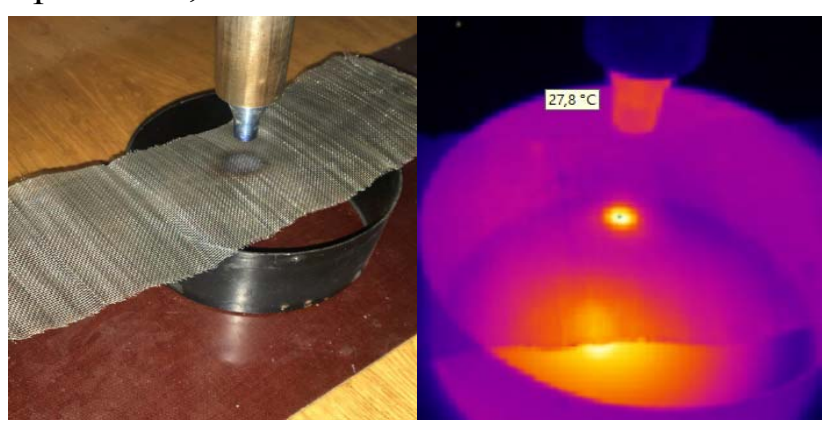

Puc. 4. Експеримент з вимірювальною площиною

Дані експерименту занесено до таблиці 3.

Таблиця 3. Температурні параметри теплового потоку експерименту з вимірювальною площиною

\begin{tabular}{|c|c|c|}
\hline $\begin{array}{c}\text { Tемпература } \\
\text { вимірювання, }{ }^{\circ} \mathrm{C}\end{array}$ & $\begin{array}{c}\text { Відстань } \\
\text { від сопла, } \\
\text { см }\end{array}$ & $\begin{array}{c}\text { Температура на } \\
\text { зрізі сопла, }{ }^{\circ} \mathrm{C}\end{array}$ \\
\hline 300 & 1 & $131 \pm 7.0$ \\
\hline 300 & 2 & $105 \pm 7.2$ \\
\hline 300 & 3 & $105 \pm 7.5$ \\
\hline 500 & 1 & $158 \pm 8.3$ \\
\hline 500 & 2 & $129 \pm 7.3$ \\
\hline 500 & 3 & $115 \pm 6.2$ \\
\hline 700 & 1 & $194 \pm 7.8$ \\
\hline 700 & 2 & $183 \pm 12.4$ \\
\hline 700 & 3 & $171 \pm 6.8$ \\
\hline
\end{tabular}


Проаналізувавши дані, можна дійти висновку, що спосіб з використанням вимірювальної площини є не точним, та займає багато часу.

Похибка складає від $\pm 6.2^{\circ} \mathrm{C}$ до $\pm 12.4^{\circ} \mathrm{C}$.

Провели дослідження за допомогою лабораторного стенду пропонованої установки (рис. 5).
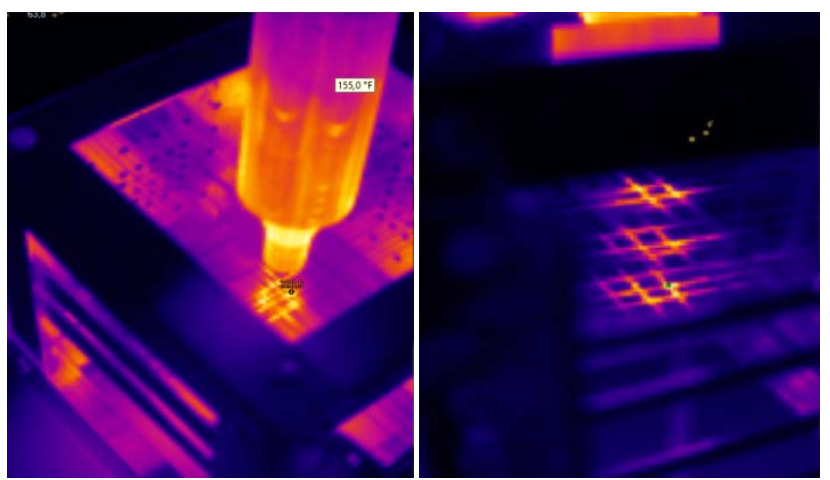

Рис. 5. Результати дослідів запропонованого лабораторного стенду

Результати експерименту показані в таблиці 4.

Таблиця 4. Температурні параметри теплового потоку експерименту з запропонованим стендом

\begin{tabular}{|c|c|c|}
\hline $\begin{array}{c}\text { Температура } \\
\text { вимірювання, }{ }^{\circ} \mathrm{C}\end{array}$ & $\begin{array}{c}\text { Відстань від } \\
\text { сопла, см }\end{array}$ & $\begin{array}{c}\text { Температура на } \\
\text { зрізі сопла, }{ }^{\circ} \mathrm{C}\end{array}$ \\
\hline 300 & 1 & $135.77 \pm 3.2$ \\
\hline 300 & 2 & $112.36 \pm 1.2$ \\
\hline 300 & 3 & $99.88 \pm 3.2$ \\
\hline 500 & 1 & $154.16 \pm 1.8$ \\
\hline 500 & 2 & $125.02 \pm 3.7$ \\
\hline 500 & 3 & $107.25 \pm 4.3$ \\
\hline 700 & 1 & $200.89 \pm 3.8$ \\
\hline 700 & 2 & $191.48 \pm 6.2$ \\
\hline 700 & 3 & $170.92 \pm 5.5$ \\
\hline
\end{tabular}

Проаналізувавши дані, можна дійти висновку, що спосіб реєстрації конвекційно-інфрачервоних потоків термохірургічного інструменту за допомогою запропонованого стенду $\epsilon$ точним.

Похибка складає від $\pm 1.8^{\circ} \mathrm{C}$ до $\pm 6.2^{\circ} \mathrm{C}$.

\section{IV. Висновки}

В даній статті запропоновано новий метод реєстрації конвекційно-інфрачервоного потоку термохірургічного інструменту, а саме розроблено лабораторний макет для реєстрації даного потоку. Спираючись на опрацьовану літературу та результати перших дослідів, було обрано технічні вимоги до стенду. Проведено порівняльний аналіз існуючих методів реєст- рації конвекційно-інфрачервоних потоків. Доказано, що запропонований метод є найбільш точним, не дорогим та не потребує багато часу. Не потребує декількох осіб персоналу, достатньо одної людини для роботи.

\section{ПЕРЕЛІК ПОСИЛАНЬ}

[1] 138 tisyach avarij i tri tisyachi zagiblix. motoroshni pidsumki realij na ukraïnskix dorogax u 2016 roci. [ 138 thousand accidents and three thousand deaths. terrible results of realities on Ukrainian roads in 2016] https:// tsn.ua/ukrayina/138-tisyach-avariy-i-tri-tisyachi-

zagiblihmotoroshni-pidsumki-realiy-na-ukrayinskih-dorogahu2016-roci-851389.htmlhttps://tsn.ua/ukrayina/138tisyachavariy-i-tri-tisyachi-zagiblih-motoroshni-pidsumkirealiy-naukrayinskih-dorogah-u-2016-roci-851389.html

[2] Bratushhak O. Vtrati v ATO. [ Loss in antiterrorist operation] http://blogs.pravda.com.ua/ authors/bratushchak/ 5992c034 $2 b 357 /-2017$

[3] Komarova O. «Vbivcya antibiotikiv»: vinaxid ukraïnskix vchenix, yakij poterpae vid byurokratiï ["The killer of antibiotics": an invention of Ukrainian scientists who suffers from the bureaucracy] // https://www.radiosvoboda.org/ /a/28834072.html. - 2017.

[4] Kosakovskij A. L., Kosakovskaya I. A., Semenov R. G. Bipolyarnye elektroinstrumenty dlya vysokochastotnoj elektrosvarki biologicheskix tkanej lor-organov // novye napravleniya issledovanij $\mathrm{v}$ oblasti svarki zhivyx myagkix tkanej: materialy pyatogo mezhdunar. Seminara [Bipolar power tools for high-frequency electrical welding of biological tissues of ENT organs // New directions of research in the field of welding of living soft tissues: Materials of the Fifth International Workshop], Kyiv, 2010

[5] KhudeckiiI. Yu., Krivcun I. V., terexov g. v. i dr. (2010) podalshe vdoskonalennya aparaturi dlya pripinennya krovotechi, obroblyannya $\mathrm{j}$ likuvannya infikovanix ran $\mathrm{z}$ vikoristannyam visokotemperaturnogo potoku [Further improvement of equipment for the discontinuation of bleeding, treatment and treatment of infected wounds using high-temperature flow], pp 53-55

[6] Search for patents - https://www.uspto.gov/patentsapplication-process/search-patents.

[7] Kyung-Hak Lee, M. D., Jooncheol Min, M. D., Kyung-Hwan Kim, M. D. (2014) Efficacy of Cox Maze IV Procedure Using Argon-Based Cryoablation: A Comparative Study with N2 OBased Cryoablation. The Korean Journal of Thoracic and Cardiovascular Surgery, 47(4), 367-372 [8] V. Vorobyev, Theory and practice of wavelet transformation, Military University of Communication, 1999. - p. 204.

[8] Taheri A, Mansoori P, Sandoval LF, Feldman SR, Pearce D, Williford PM. Electrosurgery: part II. Technology, applications, and safety of electrosurgical devices. J Am Acad Dermatol. 2014 Apr;70(4):607. DOI: 10.1016/ j.jaad.2013.09.055.

[9] Tungjitkusolmun S. (2000) Finite element modeling of radiofrequency cardiac and hepatic ablation: Electrical Engineering, Doctor of Philosophy. University of Wisconsin. Madison.

[10] Yoshimoto M, Endo K, Hanaki T, Watanabe J, Tokuyasu N, Sakamoto T, et al. Effectiveness of the LigaSure Small Jaw VesselSealing System in Hepatic Resection. Yonago Acta Med. 2014 Jun; 57(2): 93-98. 


\title{
ВИЗУАЛИЗАЦИЯ ТЕМПЕРАТУРНЫХ ПАРАМЕТРОВ КОНВЕКЦИОННО-ИНФРАКРАСНЫХ ПОТОКОВ ТЕРМОХИРУРГИЧЕСКОГО ИНСТРУМЕНТА
}

\author{
Худецкий И. Ю., проф., д.м.н. \\ igorkhudetskyy@gmail.com \\ Факультет биомедицинской инженерии \\ Национальный технический университет \\ «Киевский политехнический институт имени Игоря Сикорского» \\ г. Киев, Украина \\ Институт электросварки им. Е.О. Патона НАН Украины \\ г. Киев, Украина \\ Хрептун Е. И., студент \\ khreptun.e@gmail.com
}

\begin{abstract}
Реферат - Хирургия является одним из основных разделов в медицине. На данньй момент широко используются термохирургические аппараты для проведения оперативных вмешательств. С развитием научно-технического процесса в операционных появляются все новые и новые аппараты и устройства, которые используют практически все известные физические воздействия на ткани для выполнения определенных хирургических манипуляиий. Эффективное оказания хирургической помощи предполагает точное знание биофизического взаимодействия между електротермохирургичным инструментом и тканями в ране. Определение температурных параметров конвекиионно-инфракрасного потока термохирургичного инструмента является актуальной проблемой. Объективная оценка параметров теплового потока является залогом правильной работы термохирургичного инструмента, что приводит к успешному выполнению оперативного вмешательства. В статье предложен новый метод регистрации конвекиионно-инфракрасного потока термохирургичного инструмента, а именно разработан лабораторный стенд для регистрации данного потока. Задачей исследования было провести сравнительный анализ существуюших и предложенного методов регистраиии конвекиионно-инфракрасного потока. На первом этапе проведено исследование традиционного метода с использованием термометра на термопаре. Этот метод является наиболее неточным и трудоемким. На втором этапе для визуализации потока провели исследования с помощью измерительной плоскости. Она не имеет метрических параметров и разметки. Сетка искажает поток и вносит свои препятствия. На основе результатов первого и второго этапа исследований были выбраны технические требования к испьтательно-исследовательскому стенду регистрации конвекиионноинфракрасных потоков. Предложенный стенд может использоваться с современным тепловизионным оборудованием. Собственное влияние стенда при регистрации температурных параметров потока является минимальным. Таким образом доказано, что предложенный метод является наиболее точным, не дорогим и не требует много времени для работыл. А также не требует нескольких человек персонала, достаточно лишь одного.
\end{abstract}

Ключевые слова - визуализачия, экспериментальный стенд, термопара, тепловой поток, конвекционно-инфракрасный поток, термохирургическая аппаратура. 


\title{
VISUALIZATION OF TEMPERATURE PARAMETERS OF CONVECTION-INFRARED FLOWS OF A THERMOSURGICAL INSTRUMENT
}

\author{
I. Yu. Khudetskii, Professor, M.D. \\ igorkhudetskyy@gmail.com \\ Faculty of Biomedical Engineering \\ National Technical University of Ukraine \\ «Igor Sikorsky Kyiv Polytechnic Institute», Kyiv, Ukraine \\ E. O. Paton Institute of Electric Welding Kyiv, Ukraine \\ Y. I. Khreptun, student. khreptun.e@gmail.com
}

\begin{abstract}
Surgery is one of the main sections in medicine. At present, thermosurgical devices are widely used for surgical intervention. With the development of the scientific and technological process in the operating system, there are more and more new devices and devices that use practically all known physical effects on the fabric to perform certain surgical manipulations. Effective provision of surgical care involves accurate knowledge of the biophysical interaction between the electrotheresurgical tool and the tissue in the wound. Determination of the temperature parameters of the convection-infrared stream of the thermosurgical instrument is an urgent problem. Objective assessment of the parameters of the heat flow is a guarantee of the correct operation of the thermosurgical instrument, which leads to successful implementation of surgical intervention. The article proposes a new method for registration of convection-infrared stream of a thermosurgical instrument, namely a laboratory stand for registration of this flow. The purpose of the study was to conduct a comparative analysis of the existing and proposed methods for registration of convection-infrared stream. At the first stage, the study of the traditional method using a thermometer on a thermocouple was conducted. This method is the most inaccurate and time-consuming. In the second stage, the study was conducted using a measuring plane to visualize the flow. It does not have metric parameters and markup. The grid distorts the flow and brings its obstacles. On the basis of the results of the first and second stage of the research, technical requirements were set for the test and research stand for the registration of convection and infra-red streams. The offered booth can be used with modern thermal imaging equipment. The own influence of the stand when registering the temperature parameters of the flow is minimal. Thus, it is proved that the proposed method is the most accurate, not expensive and does not require much time to work, and also does not require a few personnel personnel, just one person.References 10, table 4, figures 5.
\end{abstract}

Keywords - visualization, experimental stand, thermocouple, heat flow, convection-infrared flow, thermosurgical equipment. 